\title{
Corrosion and Engine Test Analysis of Neem (Azadirachta indica) Oil Blends in a Single Cylinder, Four Stroke, and Air-cooled Compresion Ignition Engine
}

\author{
ABDULKADIR L. $\mathrm{N}^{1, *}$, ADISA A. B ${ }^{1}$, KYAUTA .E. $\mathrm{E}^{1}$, RAHEEM M. $\mathrm{A}^{2}$ \\ ${ }^{1}$ Mechanical Engineering Department, Abubakar Tafawa Balewa University, Bauchi, Nigeria \\ ${ }^{2}$ Computer and Communication Engineering Department, Abubakar Tafawa Balewa University, Bauchi, Nigeria \\ *Corresponding author: alfa.lukman65@gmail.com
}

Received October 24, 2014; Revised November 11, 2014; Accepted November 17, 2014

\begin{abstract}
The high energy demand in the industrial world and domestic sector as well as the pollution problems caused by emission from the use of fossil fuels as lead to an intensive research in alternative fuels sources with lesser environmental impact. One possible alternative to fossil fuel is biodiesel from vegetable oils which are currently being investigated in detail for application in compression ignition (CI) engines to increase energy security, reduce gas emissions and enhance its usage in diesel engines with little or no modifications. The objective of this study is to investigate the effects of biodiesel blends from Neem oil in $\mathrm{CI}$ engine and its corrosion rate in copper and mild steel samples. The corrosion rate of Neem biodiesel and diesel were both tested in copper and mild steel respectively. The test revealed that Neem biodiesel corrodes both test samples more than diesel. Combustion performance and emission characteristics of a single cylinder, four strokes and air-cooled diesel engine when fuelled with diesel and Neem-diesel blends at various loads was evaluated. The results showed that specific fuel consumption is better with diesel than the blends. Blends up to B20 showed higher torque, brake power and brake thermal efficiency than diesel at all loads. NOx emission increased with increase load in all the tested samples, with diesel having the least value. Fuel-Air ratio values of Neem oil biodiesel blends are less than diesel, it increases with increased load and decreased with increased blend ratio. However, there was an appreciable decrease in $\mathrm{HC}$ and $\mathrm{CO}$ emissions with increased load while there was variation in $\mathrm{CO}$ emissions with increased blend ratio and a decrease in $\mathrm{HC}$ emission. This behaviour is better with the blends than diesel due to higher oxygen content and lower carbon to hydrogen ratio in biodiesel compared to diesel.
\end{abstract}

Keywords: corrosion, Neem oil, renewable fuel, and biodiesel blends, compression ignition engine, engine test

Cite This Article: ABDUlKadiR L. N, ADISA A. B, KYAUTA .E. E, and RAHEEM M. A, "Corrosion and Engine Test Analysis of Neem (Azadirachta indica) Oil Blends in a Single Cylinder, Four Stroke, and Aircooled Compresion Ignition Engine." American Journal of Mechanical Engineering, vol. 2, no. 6 (2014): 151158. doi: 10.12691/ajme-2-6-1.

\section{Introduction}

The overwhelming challenge posed by the direct use of neat seed oil as fuel in a long term basis could be evaluated in terms of its high fuel viscosity in compression ignition engines, lower volatility and higher reactivity due to the presence of unsaturated hydrocarbon chain. However, to surmount these shortcomings, seed oils must either be heated, blended with diesel fuel or chemically altered (by alcoholysis) to prevent premature engine failure [1]. Alternatively, an engine modification designed to accommodate the conditions of use and the oil involved has also proved to be helpful [2]. Although most researchers agree that vegetable oil ester fuels are suitable for use in CIE, a few contrary results have also been obtained. The results of these studies point out that most vegetable oil esters are suitable as Diesel substitutes, but that more long-term studies are necessary for commercial utilization to become practical. Biodiesel can be used as a blend component in petrodiesel in any proportion because it is completely miscible with diesel. However, ASTM D975 and D7467 [3] only allow up to 5 and 20 vol. \% biodiesel, respectively. Biodiesel and petrodiesel are not chemically similar: biodiesel is composed of long-chain FAAE (Fatty Acid Alkyl Ester), whereas petrodiesel is a mixture of aliphatic and aromatic hydrocarbons that contain approximately 10 to 15 carbons. Because biodiesel and petrodiesel have differing chemical compositions, they have differing fuel properties. Once mixed, the blend will exhibit properties different from neat biodiesel or petrodiesel fuels. Specifically, the most important fuel properties influenced by blending of biodiesel with petrodiesel are lubricity, exhaust emissions, Cetane Number, flash point, oxidative stability, low-temperature operability, kinematic viscosity, and energy content.

Exhaust emissions of ULSD (Ultra Low Sulphur Diesel), with the exception of NOx, are reduced through 
blending with biodiesel $[4,5,6,7]$. The Cetane Number of petrodiesel is increased upon blending with biodiesel [4,5]. The flash point of petrodiesel is increased upon blending with biodiesel [8]. The oxidative stability of petrodiesel is negatively impacted upon blending with biodiesel $[9,10]$, this negative impact results to increase rate of corrosion seen in biodiesel and its blends. This is because the hydrocarbon constituents of petrodiesel are more stable to oxidation than FAME (especially in the case of unsaturated Fatty Acid Methyl Ester). Kinematic viscosity of petrodiesel increases upon blending with biodiesel $[5,8,11,12,13]$. Lastly, the heat of combustion (energy content) of petrodiesel is reduced upon blending with biodiesel $[5,11,14]$.

\section{Materials and Methods}

\subsection{Corrosion Test}

Armfield corrosion studies kit [50] was used to carry out the comparative studies of the corrosive effect of Neem seed biodiesel and petroleum diesel on metals samples like copper and milled steel. The corrosion studies kit is made up of conical flasks known as corrosion cells. Cell " $\mathrm{A}$ " was filled with biodiesel and " $\mathrm{B}$ " petroleum diesel respectively. Metal coupons of copper and milled steel were immersed in each cell and allowed to stand for 30 days at normal environmental conditions away from direct sun light. The coupons weight lost as a result of corrosion of both biodiesel and petroleum diesel actions were recorded for intervals of seven days this was achieved by recording the initial mass of the samples at the beginning of the test and that at the end of the test. The weight loss per day was determined and compared. Average weight loss (AWL), Corrosion Penetration Rate (CPR) and Corrosion Ratio (CR) of biodiesel and diesel samples were calculated using the relationship below.

\section{Surface area of coupons}

$$
\mathbf{A c}=2\{\mathrm{~T} \times \mathrm{L}+\mathrm{L} \times \mathrm{W}+\mathrm{W} \times \mathrm{T}\}-\frac{2 \pi}{4} \mathrm{D}^{2}
$$

Where: $\mathrm{T}=$ Thickness, $\mathrm{L}=$ length, $\mathrm{W}=$ Width, $\mathrm{D}=$ Diameter of hole drilled on coupons $=0.5 \mathrm{~cm}$. Thickness of copper coupons $=\mathrm{T}_{\mathrm{c}}=0.3 \mathrm{~cm}$, Length of copper coupons $=\mathrm{L}_{\mathrm{c}}=5.9 \mathrm{~cm}$, Width of copper coupons $=\mathrm{W}_{\mathrm{c}}=$ $2.2 \mathrm{~cm}$. Thickness of milled steel coupons $=T_{m}=0.3 \mathrm{~cm}$, Length of milled steel coupons $=L_{m}=4 \mathrm{~cm}$, Width of milled steel coupons $=W=2.0 \mathrm{~cm}$.

From equation 1:

Area of copper coupon $\mathrm{A}_{\mathrm{CC}}=30.34 \mathrm{~cm}^{2}$

Area of milled steel coupon $\mathrm{A}_{\mathrm{MSC}}=19.21 \mathrm{~cm}^{2}$

$$
\begin{gathered}
\mathrm{AWL}=\frac{\Sigma \text { of change in mass for the weeks }}{\text { number of weeks }} \\
\mathrm{CPR}=\frac{\mathrm{W}}{\rho \mathrm{AT}}
\end{gathered}
$$

Where $\mathrm{W}=$ weight loss, $\mathrm{T}=$ Time in days, $\mathrm{A}_{\mathrm{CC}}=30.43 \mathrm{~cm}^{2}$, $\mathrm{A}_{\mathrm{MSC}}=19.21 \mathrm{~cm}^{2}, \rho_{\mathrm{CC}}=8.92 \mathrm{~g} / \mathrm{cm}^{3}, \rho_{\mathrm{MSC}}=7.88 \mathrm{~g} / \mathrm{cm}^{3}$

$$
\mathrm{CR}=\frac{\mathrm{CPR} \text { for a coupon type in biodiesel }}{\mathrm{CPR} \text { for the same coupon type in diesel }}
$$

\subsection{Engine and Exhaust Analyses}

Technical detail of the engine used is given in Table 1. A hydraulic dynamometer was coupled to the engine for torque measurement. Experiments were conducted with transesterified Neem oil and diesel blends having 10\%, $15 \%, 20 \%, 25 \%$ and $30 \%$ transesterified Neem oil on volume basis at different load levels. The time taken by the engine to consume $8 \mathrm{ml}$ of the fuel was recorded so also was the torque, exhaust temperature and barometric pressure for all fuel samples. Tests of engine performance on pure diesel were also conducted as a basis for comparison. The percentage of blend and load, were varied and engine performance measurements such as brake specific fuel consumption, brake power, brake specific energy consumption, brake thermal efficiency and effect of load on torque. AVL DiGas 4000 gas analyzer was used to measure concentration of gaseous emissions [Oxides of nitrogen (NOx), Unburned hydrocarbon (UHC), carbon dioxide $\left(\mathrm{CO}_{2}\right)$ ] to evaluate and compute the behavior of the diesel engine at constant speed of 1500 $\mathrm{rev} / \mathrm{min}$ and varying load of between $500 \mathrm{~g}-3000 \mathrm{~g}$. The results obtained from performance analyses were tabulated and necessary graphs plotted.

Table 1. Technical specifications of engine test rig

\begin{tabular}{lr}
\hline & Single cylinder, four stroke, air-cooled \\
\hline Bore * Stroke & $65 \mathrm{~mm} \times 70 \mathrm{~mm}$ \\
Brake power & $2.43 \mathrm{~kW}$ \\
Rated speed & $1500 \mathrm{rpm}$ \\
Starting method & Manual cranking \\
Compression ratio & $20.5: 1$ \\
Net weight & $45 \mathrm{Kg}$ \\
Manufacturer & TQ Educational Training Ltd \\
\hline
\end{tabular}

\section{Results and Discussion}

\subsection{Corrosion Value}

The corrosion rate of Neem biodiesel and diesel were both tested in copper and mild steel respectively. The test revealed that Neem biodiesel corrodes both test samples more than diesel (Table 2). Biodiesel is believed to contain residual water because of transesterification; this could be responsible for higher rate of corrosion. Many of the parts in the diesel fuel injection system are made of high carbon steels; thus, they are prone to corrosion when in contact with water. Water damage is a leading cause of premature failure of fuel injection systems. The water content of petroleum diesel is usually quite low since hydrocarbons are generally hydrophobic. Fatty acid esters, on the other hand, are hygroscopic and will contain high water content by merely being exposed to moist air during storage. Water will cause corrosion of vital fuel system components fuel pumps, injector pumps, fuel tubes, etc [15]. Also the higher the acid value of biodiesel the more it corrodes. Neem biodiesel has an appreciably high acid value above the benchmark standards given by both ASTM [3] and DIN V 51606 [16].

Table 2. Corrosion test of biodiesel using armfield corrosion test kit

\begin{tabular}{lccc}
\hline Sample immersion & Metal coupons & W & CPR \\
\hline Samples immersed & Milled steel & 0.015 & $1.416 \times 10^{-5} \mathrm{~cm} /$ day \\
in biodiesel & Copper & 0.0525 & $2.763 \times 10^{-5} \mathrm{~cm} /$ day \\
$\begin{array}{l}\text { Samples immersed } \\
\text { in petroleum }\end{array}$ & Milled steel & 0.0125 & $1.180 \times 10^{-5} \mathrm{~cm} /$ day \\
diesel & Copper & 0.0225 & $1.184 \times 10^{-5} \mathrm{~cm} /$ day \\
\hline
\end{tabular}


Corrosion Ratio (CR)

$$
\begin{aligned}
& \text { CR for Copper coupons }=\frac{2.763 \times 10^{-5}}{1.184 \times 10^{-5}}=2.334 \\
& \text { CR for Milled steel coupons }=\frac{1.416 \times 10^{-5}}{1.180 \times 10^{-5}}=1.2
\end{aligned}
$$

\subsection{Engine Performance}

\subsubsection{Brake Specific Fuel Consumption (BSFC)}

The BSFC is a measure of the efficiency of the engine in using the fuel supplied to produce work. It is desirable to obtain a lower value of BSFC meaning that the engine used less fuel to produce the same amount of work. Figure 1, illustrates the variation of brake specific fuel consumption of samples at different loads. The BSFC in general, was found to increase with increasing proportion blend; this could be due to the high mass flow of fuel entering into the engine. As load increases, BSFC decreases to a minimum and then increases. The improvement in BSFC was due to better combustion of the fuel, which may be attributed to the presence of oxygen in the blend. The specific fuel consumption was found to be higher in all the blends than diesel due to the combined effects of lower heating value and the higher fuel flow rate caused by high density of the blends which caused high mass injection for the same volume at the same injection pressure. At concentration above $20 \%$ the variations in the specific fuel consumption are significant due to decreased calorific value, increased viscosity and poor atomization of the fuel. The appreciably higher BSFC of biodiesel could be explained in terms of higher specific gravity, higher viscosity and heating values of biodiesel and this indicates higher fuel consumption per unit of power produced due to low combustion efficiency $[17,18]$. High fuel viscosity results in reduced quality of fuel atomization, higher gas emission and fuel consumption [19]. BSFC decreases for all fuels at higher load because percent increase in fuel required to operate the engine is less than the percent increase in brake power, an indication that compression ignition engines run efficiently at higher load than at part load [20]. Oxygen improves the efficiency of combustion, but it takes up space in the blend and therefore slightly increases the apparent fuel consumption rate observed while operating an engine with biodiesel [21]. BSFC is expected to increase by around $14 \%$ when using biodiesel in relation with diesel fuel, corresponding to the increase in heating value in mass basis which is compensated for with higher fuel consumption [7].

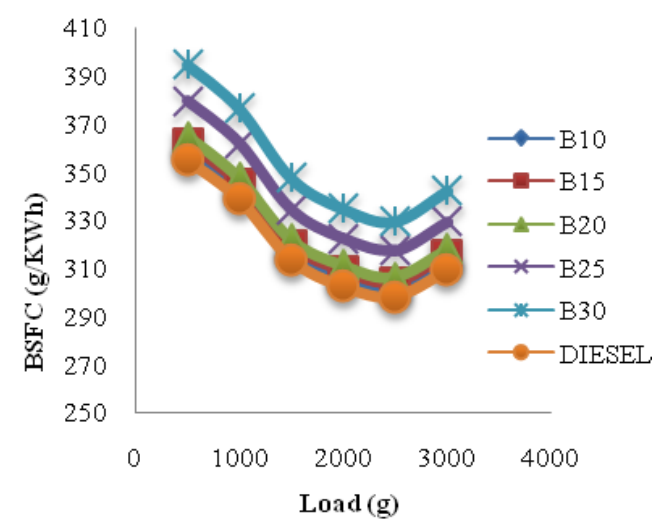

Figure 1. Variation of BSFC for diesel and blends with increase in load

\subsubsection{Brake Power}

The influence of load on brake power for different fuels is presented in Figure 2. As the load increases, brake power increases and then decreased for all the fuel samples. BP of B10, B15 and B20 are higher than that of diesel; this could be attributed to their improved calorific (heating) value as it combines with conventional diesel fuel to burn. BP of B25 is almost the same with that of diesel while that of B30 is less than that of diesel due to reduced torque caused by increased lubricity of biodiesel in the blend. Behaviuor of biodiesel blends is affected by its viscosity profile, because fuel viscosity influences fuel injection and combustion. Hence, high fuel viscosity reduces fuel injection efficiency and atomization, and could adversely affect fuel combustion leading to power losses in engine(s) [19,22]. As the concentration of biodiesel in fuel blends increases, the adsorption layer on metal surface in relative motion to one another (such as, injector system, pistons, rings and sleeves) become better lubricated and initiate a declination of frictional horse power. This improved lubrication conditions enhances engine power output and brake mean effective pressure respectively $[18,23]$. Pongamia pinnata methyl ester blend in diesel engine resulted in reduced exhaust emission, brake-specific fuel consumption, increase in torque, brake power and brake thermal efficiency [24]. Gumus and Kasifoglu [25], used a single cylinder, 4-stroke, air-cooled diesel engine and found that engine power increased with the addition of biodiesel in the blends reaching a maximum value at B20. When the biodiesel content continued to increase in the blends, the power decreased below that of the diesel fuel and reached minimum value for B100. Power initially increased with the addition of biodiesel, reached a maximum value, and then decreased with further increase of the biodiesel content [26].

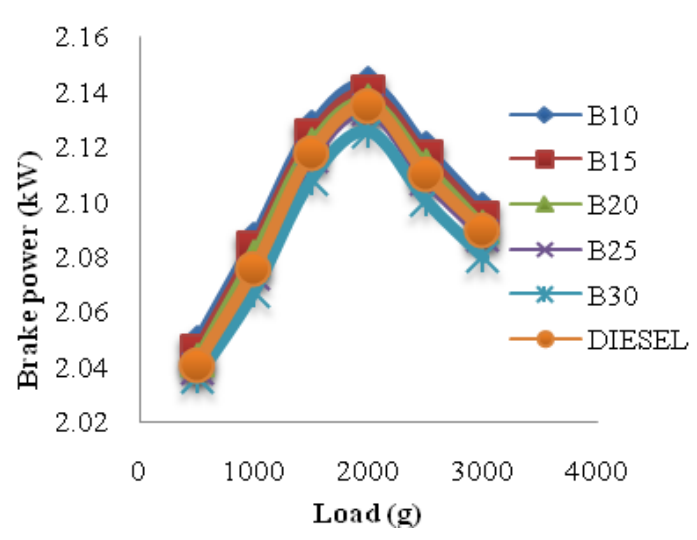

Figure 2. Variation of BP for diesel and blends with increase in load

\subsection{Brake Thermal Efficiency (BTE)}

Thermal efficiency is the ratio between the power output and the energy introduced through fuel injection. BTE gives an idea of the output generated by the engine with respect to heat supplied in the form of fuel. The variation of BTE with load is shown in Fig. 3. For all fuels, BTE increases with increase in load, attributed to the increase in power with increase in load. The initial increase in BTE may be due to complete and high combustion of fuel, but once the load reached $2500 \mathrm{~g}$; the time taken for complete combustion of fuel decreased, hence a slight drop in BTE was observed. Oxygen present 
in the blends perhaps also helped in complete combustion of fuel at low load conditions. BTE of B10, B15 and B20 are higher than that of diesel at all loads with B20 having the highest value, while those of B25 and B30 were less than that of diesel. The low BTE obtained could be due to reduction in calorific value and increase in fuel consumption as compared to B10, B15 and B20. It may also be due to their low heat input requirement for higher power output at a given load. As the proportion of biodiesel in the blends increases, BTE decreased due to the poor atomization of the blends because of their high viscosity. Rao et al. [27] investigated the performance of Neem methyl and reported that the BTE of B10, B20 blends were very close to that of diesel. Ragit et al. [28] also observed that BTE increases for all the blends of Neem tested but not more than diesel. The falling off in thermal efficiency are due to increase mechanical losses in engine relative to useful power output, throttling losses and deterioration in combustion efficiency, with increasing concentration of the biodiesel in the SHOMEDiesel fuel mixture [29,30,31]. Bagby et al. [32] said "Specific gravity of vegetable oils plays an important role in affecting the performance of engine at full load levels. They reported about a slight drop in efficiency in case of methyl ester as compared to diesel which was attributed to its high viscosity". Ramadhas et al. [33] tested 10\%, 20\%, $50 \%, 75 \%$ blends and pure biodiesel from rubber seed oil and obtain maximum efficiencies for $10 \%$ and $20 \%$ blends which was explained by the increased lubricity of these blends as compared to their pure components. The maximum thermal efficiency for B20 was higher than that of diesel while that of B40, B60 and B100 were less and this was attributed to reduced calorific value and increased fuel consumption as compared to B20. This blend of $20 \%$ also gave minimum brake specific energy consumption. Hence, this blend was selected as optimum blend for further investigations and long-term operation [34]. In the Handbook of Biodiesel, it was asserted that an improvement in thermal efficiency occurs when $20 \%$ blends are used, thereby compensating for the loss of heating value. However, no references are cited to support this statement.

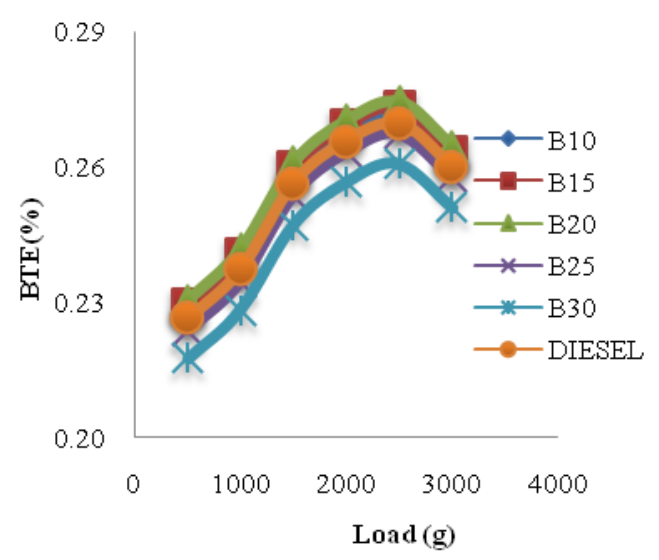

Figure 3. Variation of BTE for diesel and blends with increase in load

\subsection{Effect of Load on Torque}

The relationship between the load and torque for various fuels is shown in Figure 4. It was observed that torque increases with increases in load due to increase in fuel consumption with increase in load. Torque increased to the maximum at $2500 \mathrm{~g}$ load and then it decreases for all the fuel samples due to higher Cetane number of biodiesel, higher calorific value of diesel and that of the dual fuel mixtures from B10 to B20, as well as complete combustion of fuels. Fuel with higher proportions of biodiesel gave less torque due to lesser energy released attributed to the low calorific value of the NOME. Both torque and brake power increased with increase in load due to increase in fuel consumption with increase in load. The torque and brake power produced in case of B20 and B40 were higher than that of diesel while that of B60 to $\mathrm{B} 100$ are lesser due to complete combustion of fuels and decrease in calorific value of fuel [35]. Altiparmak et al. [5] measured an increase in torque when they used a blend with $70 \%$ tall oil biodiesel, with respect to that measured with diesel fuel. Although they explained this increase with the increased Cetane number, unusually high values of density and viscosity of the biodiesel tested could also partially explain such a result [7]. Song and Zhang [35] observed that the engine brake power and torque increased with the increase in biodiesel percentage in the blends. And they contributed to the higher oxygen content, the higher biodiesel consumption, an advance of injection timing and a shorter ignition delay time. Aydin et al. [36] reported that the torque decreased with increase in CSOME (cottonseed oil methyl ester) in the blends (B5 B20 B50 B75 B100) due to higher viscosity and lower heating value of CSOME.

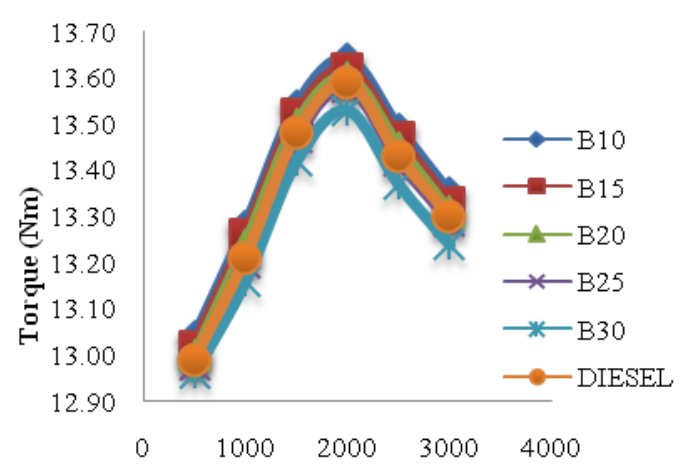

$\operatorname{Load}(g)$

Figure 4. Variation of torque for diesel and blends with increase in load

\section{5. $\mathrm{NO}_{\mathrm{X}}$ Emission of Diesel and Neem Biodiesel Blends}

It is well known that nitrogen is an inert gas, but it remains inert up to a certain temperature $\left(1100^{\circ} \mathrm{C}\right)$ and above this level it does not remain inert and participates in chemical reaction. At the end of combustion, gas temperature inside cylinder rises around $1500^{\circ} \mathrm{C}$. At this temperature oxidation of nitrogen takes place in inside the cylinder. On the other hand, since the formation of nitrogen oxides do not attain chemical equilibrium reaction, then after the end of expansion stroke when the burned gases cool and the formation of $\mathrm{NO}_{\mathrm{x}}$ freeze, the concentration of the formed $\mathrm{NO}_{\mathrm{x}}$ in the exhaust gas remain unchanged. $\mathrm{NO}_{\mathrm{x}}$ emission for diesel and all the blends followed an increasing trend with respect to load (Figure 5 ). The blends have higher $\mathrm{NO}_{\mathrm{x}}$ emission at all loads when compared to diesel due to the slower burning character of the blends which caused a slight delay in the energy 
release resulting to high temperature in the later part of power and exhaust stroke. This high temperature favours the formation of nitric oxide.

At higher loads, more fuel is burnt and higher temperature of the exhaust gases results in higher production of nitric oxide. $\mathrm{NO}_{\mathrm{x}}$ emission increased with increase in percentage blend which may be associated with the oxygen content of the biodiesel, since the oxygen present in the fuel may provide additional oxygen for $\mathrm{NO}_{\mathrm{x}}$ formation. As biodiesel contains no nitrogen, the increase in $\mathrm{NO}_{\mathrm{x}}$ emissions may also be due to the higher Cetane rating of biodiesel and higher oxygen content, which allows it to convert nitrogen from the atmosphere into $\mathrm{NO}_{\mathrm{x}}$ more rapidly. As the load increases, the overall fuelair ratio increases due to an increase in the average gas temperature in the combustion chamber and hence $\mathrm{NO}_{\mathrm{x}}$ formation. The $\mathrm{NO}_{\mathrm{x}}$ level was found to be directly related to the exhaust gas temperature (i.e. NOx emission is related to average cylinder gas temperature) and inversely related to the $\mathrm{CO}$ values. $\mathrm{NO}_{\mathrm{x}}$ emissions are associated with high gas temperatures and lean fuel conditions; in contrast to most other pollutants, they usually increase when biodiesel is used [26]. Mittelbach and Remschmidt [27] suggested that the higher oxygen content bio-diesel possesses could cause the increase, due to an abundance of oxygen in the combustion chamber. Yuan et al [28] and Choi and Reitz [29] both obtained reduced auto-ignition times and higher extension of the high-temperature areas when using biodiesel fuels. They used these results to explain the observed increase in NOx emissions. Peterson et al. [30] observed increase in $\mathrm{NO}_{\mathrm{x}}$ emissions with increasing values of the iodine number. Graboski et al. [31] explained that iodine number is closely related to density, compressibility and cetane number, and suggested that the observed increase in $\mathrm{NO}_{\mathrm{x}}$ could be caused by the above discussed effects on the injection or combustion timing rather than by the molecular unsaturation. Leung et al. [32] proposed increases in the injection pressure or even changes in the size of some injection pump components in order to eliminate the expected NOx emissions. Chapman et al [33] confirmed that selecting a more saturated biodiesel fuels leads to reduction in NOx emissions.

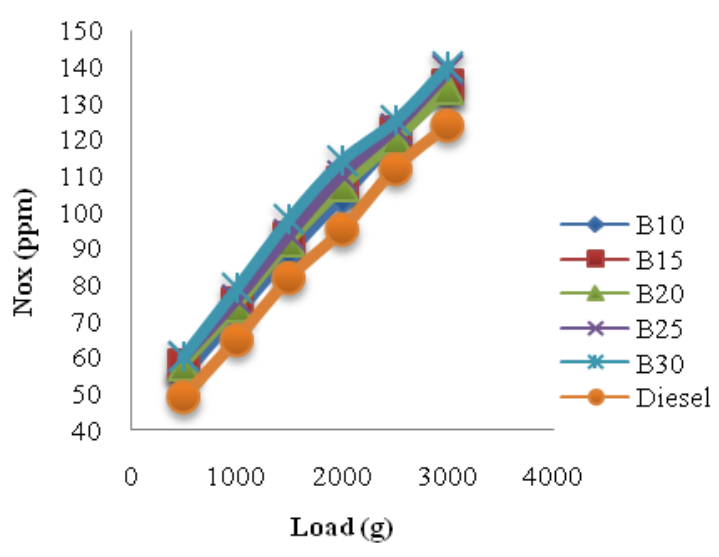

Figure 5. Emission of NOx for all samples with increase in load

\subsection{Fuel-Air Ratio (FAR)}

Fuel-air ratio (FAR) is the ratio of the mass of fuel to the mass of air input into the engine. Air-fuel ratio (AFR) is reciprocal of fuel-air ratio. Fuel-air ratio of the mixture affects the combustion phenomenon in that it determines the flame propagation velocity, the heat release in the combustion chamber, the maximum temperature and the completeness of combustion. Figure 6 shows the variation of fuel-air ratio with load for all tested samples. In C.I engines at a given speed the air flow do not vary with load, it is the fuel flow that varies directly with load. As seen from the figure below, as percentage blend increases the fuel-air ratio decreases but increases with increase in load. Fuel-air ratio values of Neem oil biodiesel blends are less than diesel. Except for B25 and B30 NOME-Diesel fuel blends, which demonstrated average difference of $6.18 \%$ and $9.4 \%$ from the FAR of diesel fuel, B10, B15 and B20 NOME-Diesel fuel are $1.78 \%, 2.24 \%$ and $2.81 \%$ lower than diesel fuel benchmark respectively. The observation made from this finding is that all tested fuel samples reached maximum power output and torque at higher than the stoichiometric AFR values (i.e. 18-25) for compression ignition engines. In this case, maximum power output is achieved at rich mixture, therefore causing the engine to run at higher engine temperature. As load is increased, the overall fuel-air ratio increased which resulted in an increase in the average gas temperature in the combustion chamber, this trend also was illustrated in literatures [51,52,53]. At lower load combustion conditions, the fuel air ratio becomes too lean for a complete combustion especially at lower engine speeds. When the engine is running on biodiesel, the extra oxygen atoms contained in the biodiesel further reduces the fuel-air ratio, causing the flame temperature to drop very fast, resulting in a higher $\mathrm{CO}$ emission experienced at low load. The stoichiometric AFR values of engines running on biodiesel are usually lower than diesel fuel because more oxygen presence is evident in biodiesel due to the methanolysis of sheanut oil, and it enabled SHOME blended fuel samples to burn much richer than diesel fuel [45].

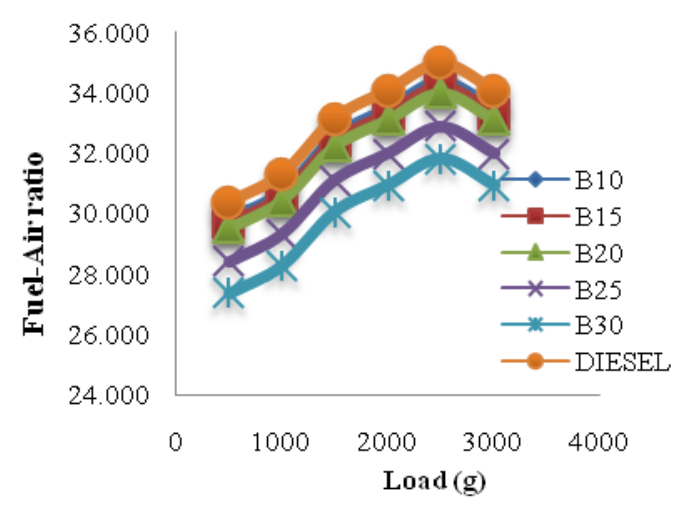

Figure 6. Variation of Air/Fuel ratio for all samples with increase in load

\subsection{CO Emission of Diesel and Neem Biodiesel Blends}

The variation of $\mathrm{CO}$ emission with load is shown in Figure 7. It was observed that the engine emits more $\mathrm{CO}$ for diesel at all load conditions when compared to the blends. However, as the proportion of NOME in the blend increases the percentage emission decreases due to higher oxygen content and lower carbon to hydrogen ratio in biodiesel compared to diesel. The percentage variation of carbon monoxide for all the blends when compared with base line diesel is very much less. These lower CO emissions of biodiesel blends may be due to their more 
complete oxidation as compared to diesel. Some of the CO produced during combustion of biodiesel might have converted to $\mathrm{CO}_{2}$ by taking up the extra oxygen molecule present in the biodiesel chain (Biodiesel has up to $11 \%$ oxygen content: [28]) and thus reduced $\mathrm{CO}$ formation. It can be observed from Figure 4 that the $\mathrm{CO}$ initially decreased with load and latter increased at higher load. This trend was observed for all the fuel blends tested. At lower biodiesel concentration, the oxygen present in the biodiesel aids for complete combustion. However as the biodiesel concentration increases, the negative effect due to high viscosity and small increase in specific gravity suppresses the complete combustion process, which produces small amount of $\mathrm{CO}$ [46]. Last et al. [47] fuelled a heavy-duty engine with $10 \%, 20 \%, 30 \%, 50 \%$ and $100 \%$ soybean-oil biodiesel. All the blends reduced $\mathrm{CO}$ emissions with respect to the diesel fuel, but such decreases did not depend on the biodiesel percentage (10\%, $8 \%$, $18 \%, 6 \%$ and $14 \%$ reductions, respectively). Also, Rakopoulos et al. [48] reported lower CO concentration in the exhaust line when oxygen in the combustion chamber was increased either with oxygenated fuels or oxygenenriched air.

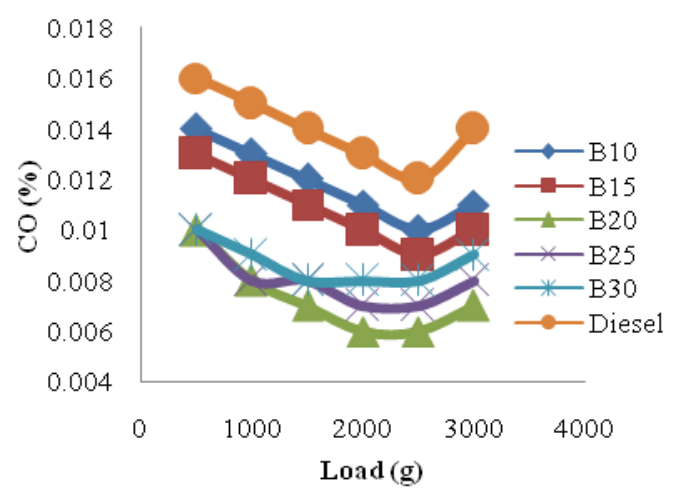

Figure 7. Emission of $\mathrm{CO}$ for all samples with increase in load

\subsection{HC Emission of Diesel and Neem Biodiesel Blends}

Most unburned hydrocarbon emissions results from fuel droplets that were transported or injected into the quench layer during combustion. Partially burned hydrocarbons can occur because of poor air and fuel homogeneity due to incomplete mixing, before or during combustion; incorrect air/fuel ratios in the cylinder during combustion due to maladjustment of the engine fuel system; excessively large fuel droplets (diesel engines); and low cylinder temperature due to excessive cooling (quenching) through the walls or early cooling of the gases by expansion of the combustion volume caused by piston motion before combustion is completed [54].

The HC emission variation for different blends is indicated in Figure 8. All blends have lower values than diesel owing to higher combustion chamber temperature, which helps in cracking and faster burning. It was observed that the HC emission decreased up to a load of $2500 \mathrm{~g}$ and then increased slightly with further increase in load for all the samples. The HC emission for the blends also followed a similar trend but comparatively the values were lower. The presence of oxygen in the Neem blends aids combustion and hence the hydrocarbon emission reduced. It was suggested that the short ignition delay when using biodiesel due to higher Cetane number could also attribute to lower $\mathrm{HC}$ emissions [7]. Many authors [55,56,57] agreed that $\mathrm{HC}$ emissions decreases with increasing biodiesel percentage in the blend. Godiganur et al. [58] found that the reduction in $\mathrm{HC}$ was linear with the addition of biodiesel for the blends. Rakopoulos et al. [48] concluded in their review that $\mathrm{HC}$ emissions decreased as the oxygen in the combustion chamber increased, either with oxygenated fuels or oxygen- enriched air. Sahoo et al. [49] reported that the reduction of $\mathrm{HC}$ was of the order of $32.28 \%, 18.19 \%$ and $20.73 \%$ for JB20, JB50, JB100, respectively.

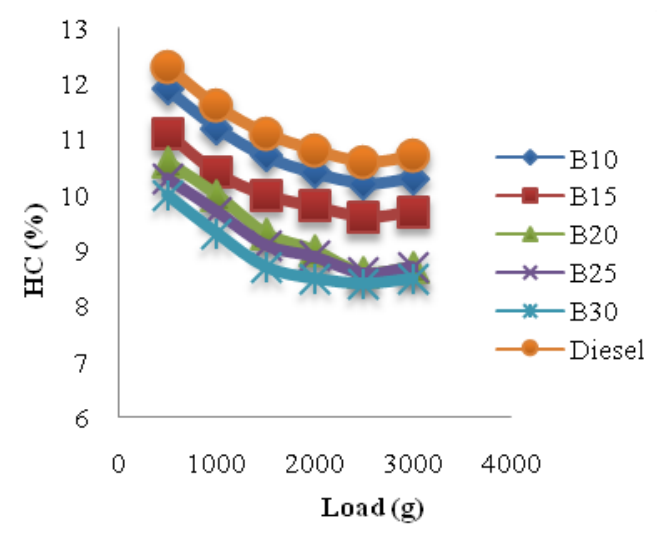

Figure 8. Emission of $\mathrm{HC}$ for all tested samples with increase in load

\section{Conclusion}

Corrosion test carried out revealed that Neem biodiesel corrodes both test samples more than diesel; this was possible because biodiesel is believed to contain residual water due to transesterification. Another important issue worth mentioning is the fact that Fatty acid esters are hygroscopic and will contain high water content by merely being exposed to moist air during storage. All the above put together are believed to be responsible for higher rate of corrosion observed in biodiesel. Brake specific fuel consumption of diesel showed the best result while among the blends B10 is better. Brake power of B10, B15 and B20 are better than that of diesel while that of B10 is equally the best among the blends. Brake thermal efficiency was best with B20 than diesel and other blends while B10 has highest torque than diesel and other blends. Diesel had the lowest NOx emissions followed by B10; it increases with increased blend ratio, this increase is mainly due to higher oxygen content for biodiesel. As percentage blend increases the Air-fuel ratio decreases but increases with increase in load. Air-fuel ratio values of Neem oil biodiesel blends are less than diesel. B30 gave the best and least ratio. The engine emits more $\mathrm{CO}$ for diesel at all load conditions when compared to the blends, however, as the proportion of NOME in the blend increases the percentage emission decreases. $\mathrm{HC}$ emission was lower in blends than diesel and decreases with increase in load and percentage NOME.

\section{References}

[1] Radu R, Mircea Z. The use of sunflower oil in Diesel engines. Transactions of Society of Automotive Engineers, Paper No.972979, USA. 1995. 
[2] Srivastava A, Prasad R. Triglycerides-based diesel fuels. Renewable Sustainable Energy Review, 2000; 4: 111-133.

[3] ASTM 1982. ASTM Standard parts 17 and 18. American Society of Testing and Materials. Philadelphia, Pennsylvania. (D975-08a Specification for Diesel Fuel Oils (on and off-road applications; D7467-08 Specification for Diesel Fuel Oil, Biodiesel Blend B6 to B20).

[4] Chang, D. Y. Z., Van Gerpen, J. H., Lee, I., Johnson, L. A., Hammond, E. G. and Marley S. J. (1996). Fuel properties and emissions of soybean oil esters as diesel fuel. Journal of the American Oil Chemists' Society 73, 1549-1555.

[5] Altiparmak, D., Keskin, A.. Koca, A. \& Guru, M. (2007). Alternative fuel properties of tall oil fatty acid methyl ester-diesel fuel blends. Bioresource. Technology. 98, 241-246.

[6] Korres, D. M., Karonis, D., Lois, E., Linck, M. B. and Gupta, A. K. (2008). Aviation fuel JP-5 and biodiesel on a diesel engine. Fuel. 87, 70-78.

[7] Lapuerta, M., Octavio, A. and Jose', R. (2008). Effect of biodiesel fuels on diesel engine emissions. Progress in Energy and Combustion Science. 34,198-223.

[8] Alptekin, E. \& Canakci, M. (2009) Characterization of the key fuel properties of methyl ester-diesel fuel blends. Fuel. 88, 75-80.

[9] Mushrush, G. W., Wynne, J. H., Hughes, J. M., Beal, E. J. and Lloyd, C. T. (2003). Soybean-derived fuel liquids from different sources as blending stocks for middle distillate ground transportation fuels. Ind. Eng. Chem. Res. 42, 2387-2389.

[10] Mushrush G. W., Wynne, J. H., Willauer, H. D., Lloyd, C. T., Hughes, J. M. and Beal E. J. (2004). Recycled soybean-cooking oils as blending stocks for diesel fuels. Ind. Eng. Chem. Res. 43, 4944-4946.

[11] Benjumea, P., Agudelo, J. \& Agudelo, A. (2008). Basic properties of palm oil biodiesel-diesel blends. Fuel. 87, 2069-2075.

[12] Moser B. R. (2008). Efficacy of myricetin as an antioxidant additive in methyl esters of soybean oil. European Journal of Lipid Science Technology. 110, 1167-1174.

[13] Alptekin E. \& Canakci M. (2008). Determination of the density and the viscosities of biodiesel-diesel fuel blend. Renewable Energy. 33, 2623-2630.

[14] DeOliveira, E., Quirino, R. L., Suarez, P. A. Z. and Prado, A. G. S. (2006). Heats of combustion of biofuels obtained by pyrolysis and by transesterification and of biofuel/diesel blends. Thermochim. Acta. 450, 87-90.

[15] Ayhan Demirbas. (2009). Progress and recent trends in biodiesel fuels. Journal of Energy Conversion and Management. 50, 14-34.

[16] DIN V 51606. Deutsches Institut für Normung e.V.( German Institute for Standardization)

[17] Bhattacharya, T. K., Chandra R., and Mishra, T. N. (2006, June). Performance characteristics of a stationary constant speed compression ignition engine on alcohol-diesel micro emulsions. Agricultural Engineering International: the CIGR Journal of Scientific Research and Development. Manuscript EE 04 002. Vol. VIII

[18] Masjuki, H. H. and Maleque, M.A. (1996). Wear performance and emission of a two-stroke engine running or palm oil methyl ester blended lubricant I.Mech. E. Journal of Engineering Tribology. Proceeding part J. 210 (J4), 213-219.

[19] Wirawan, S. S., Tambunan, A. H., Djamin, M. and Nabetani, H. (2008, April). The effect of palm biodiesel fuel on the performance and emission of the automotive diesel engine. Agricultural Engineering International: The CIGR Journal of Scientific Research and Development. Manuscript EE 07 005. Vol. $\mathrm{X}$.

[20] Praveen, K. S., Yadav., Onkar, Singh. \& Singh, R. P. (2010, November). Performance test of palm fatty acid biodiesel on compression ignition engine. Journal of petroleum Technology and Alternative Fuels. 1(1), 1-9.

[21] Demirbas A. (2009). Progress and recent trends in biodiesel fuels Energy Conversion and Management. 50, 14-34.

[22] Knothe, G. J., V. Gerpen and J. Krahl, (2004). The Biodiesel handbook. American Oil Chemists' Society Press, Illinois.

[23] Sabeena, S. M., Igba, A., Das, P., Patel, R. and Ganesh, A. (2004). Biodiesel from non-edible oil- a fuel for future. In proc. chem. Con. 04 Mumbai, held at IIT Bombay.

[24] Raheman, H. and Phadatare, A. G., (2004). Diesel engine emissions and performance from blends of karanja methyl ester and diesel. Biomass Bioenergy, 27: 393-7.

[25] Gumus, M. and Kasifoglu, S. (2010). Performance and emission evaluation of a compression ignition engine using a biodiesel (apricot seed kernel oil methyl ester) and its blends with diesel fuel. Biomass Bioenergy. 34, 134-9.

[26] Usta, N. (2005). Use of tobacco seed oil methyl ester in a turbocharged indirect injection diesel engine. Biomass Bioenergy, 28:77-86.

[27] Rao, T. V., Rao, G. P. and Reddy, K. H. C. (2008). Experimental investigation of pongamia, jatropha and neem methyl esters as biodiesel on C.I. engine. Jordan Journal of Mechanical and Industrial Engineering 2(2):117-22.

[28] Ragit, S. S., Mohapatra, S. K. and Kundu, K. (2010). Performance and emission evaluation of a diesel engine fuelled with methyl ester of neem oil and filtered neem oil. J Sci Ind Res, 69, 62-6.

[29] Pathak, B.S. (2004). The relevance of biomass management. In proceeding: National seminar on Biomass Management for Energypurposes: Issue and strategies: held at SPRERI,VV Nagar: $1-9$.

[30] Singh, R.N., Singh, S.P., and Pathak, B. S. (2007, April). Performance of renewable fuel based C.I. engine. Agricultural Engineering International: The CIGR E journal of Scientific Research and Development. Manuscript EE 0014. Vol. IX.

[31] Plint and Partners (1984): Shell- Plint Engine Test Bed Manual. Plint and Partners Publications, England, Pp 8-14.

[32] Bagby, M. O. (1996). Biofuels, and other emerging products from vegetable oils. In Princen L. H. \& Rossi, C. (Eds.) Proceedings of the 9th international conference on jojoba and its uses. Third international conference on new industrial crop products (p. 220224). Association for the Advancement of Industrial Crops, Phoenix, AZ.

[33] Ramadhas, A. S., Muraleedharan, C. and Jayaraj, S. (2005). Performance and emission evaluation of a diesel engine fueled with methyl esters of rubber seed oil. Renewable Energy 30: 1789800 .

[34] Sharanappa, G., Suryanarayana, M. C. H. \& Rana, P. R. (2009). 6BTA 5.9 G2-1 Cummins engine performance and emission tests using methyl ester mahua (Madhuca indica) oil/diesel blends. Renewable Energy 34: 2172-2177.

[35] Song, J. T. and Zhang, C. H. (2008). An experimental study on the performance and exhaust emissions of a diesel engine fuelled with soybean oil methyl ester. P I Mech Eng D-J Aut, 222: 2487-96.

[36] Aydin, H. and Bayindir, H. (2010). Performance and emission analysis of cottonseed oil methyl ester in a diesel engine. Renewable Energy. 35, 588-592.

[37] Sharp, C.A., S.A. Howell, and J. Jobe. (2000). The Effect of Biodiesel Fuels on Transient Emissions from Modern Diesel Engines, Part I. Regulated Emissions and Performance, Society of Automotive Engineers Paper No. 2000-01-1967.

[38] Mittelbach, M. and Remschmidt. C. (2004). Biodiesel-The Comprehensive Handbook, Graz, Austria: Martin Mittelbach.

[39] Yuan, W., Hansen, A. C., Tat, M. E., Van Gerpen, J. H. and Tan, Z. (2005). Spray, ignition and combustion modeling of biodiesel fuels for investigating NOx emissions. Transactions of the American Society of Agricultural Engineers 48(3): 933-9.

[40] Choi, C. Y. and Reitz, R. D. (1999). A numerical analysis of the emissions characteristics of biodiesel blended fuels. J Eng Gas Turbines Power. 121, 31-7.

[41] Peterson, C. L., Taberski, J. S., Thompson, J. C. \& Chase, C. L. (2000). The effect of biodiesel feedstock on regulated emissions in chassis dynamometer tests of a pickup truck. Transactions of the American Society of Agricultural Engineers. 43, 1371-1381.

[42] Graboski, M. S., McCormick, R. L., Alleman, T. L. and Herring, A. M. (2003). The effect of biodiesel composition on engine emissions from a DDC series 60 diesel engine. National Renewable Energy Laboratory NREL/SR-510-31461

[43] Leung, D. Y. C., Luo, Y. and Chan, T. L. (2006). Optimization of exhaust emissions of a diesel engine fuelled with biodiesel. Energy Fuels. 20, 1015-23.

[44] Chapman, E., Hile, M., Pague, M., Song, J. and Boehman, A. (2004). Eliminating the NOx emissions increase associated with biodiesel. In: The 95 $5^{\text {th }}$ American Oil Chemists' Society annual meeting (Expo2004).

[45] Goering, C.F. (1992). Engine Tractor Power. Copyright Edition. American Society of Agricultural Engineers Publications, Michigan: 358-362.

[46] Sureshkumar, K. and Velra, R. (2007). Performance and Characteristics Study of the Use of Environment Friendly Pongamia Pinnata Methyl Ester in C. I. Engines. Journal of Energy \& Environment, 5: 60-71. 
[47] Last, R. J., Kru" ger, M. and Du" rnholz, M. (1995). Emissions and performance characteristics of a 4-stroke, direct injected diesel engine fueled with blends of biodiesel and low sulfur diesel fuel. Society of Automotive Engineers paper 950054.

[48] Rakopoulos, C. D., Hountalas, D. T., Zannis, T. C. and Levendis, Y. A. (2004). Operational and environmental evaluation of diesel engines burning oxygen-enriched intake air or oxygen-enriched fuels: a review. Society of Automotive Engineers paper -01-2924.

[49] Sahoo, P. K., Das, L. M., Babu, M. K. G., Arora, P., Singh, V. P., Kumar, N. R, et al. (2009). Comparative evaluation of performance and emission characteristics of jatropha, karanja and polanga based biodiesel as fuel in a tractor engine. Fuel. 88: 1698707.

[50] Armfield Corrosion studies kit-ceq. November 1995. www.armfield.co.uk/ceq.

[51] Zhu L, Zhang W, Liu W, Huang Z. Experimental study on particulate and NOx emissions of a diesel engine fueled with ultra low sulfur diesel, RME-diesel blends and PME-diesel blends. Sci Total Environ 2010; 408: 1050-8.

[52] Deshmukh SJ, Bhuyar LB. Transesterified Hingan (Balanites) oil as a fuel for compression ignition engines. Biomass Bioenerg 2009; 33: 108-12.
[53] Raheman H, Ghadge SV. Performance of compression ignition engine with mahua (Madhuca indica) biodiesel. Fuel 2007; 86: 2568-73.

[54] Standards Support And Environmental Impact Statement, Volume 1: Stationary Internal Combustion Engines, EPA-450/2-78-125a, U. S. Environmental Protection Agency, Research Triangle Park, NC, July 1979.

[55] Ghobadian B, Rahimi H, Nikbakht AM, Najafi G, Yusaf TF. Diesel engine performance and exhaust emission analysis using waste cooking biodiesel fuel with an artificial neural network. Renew Energ 2009; 34: 976-82.

[56] Song J-T, Zhang C-H. An experimental study on the performance and exhaust emissions of a diesel engine fuelled with soybean oil methyl ester. P I Mech Eng D-J Aut 2008; 222: 2487-96.

[57] Kim H, Choi B. The effect of biodiesel and bioethanol blended diesel fuel on nanoparticles and exhaust emissions from CRDI diesel engine. Renew Energ 2010; 35: 157-63.

[58] Godiganur S, Murthy CHS, Reddy RP. Performance and emission characteristics of a Kirloskar HA394 diesel engine operated on fish oil methyl esters. Renew Energ 2010; 35: 355-9. 